\title{
THE STORY OF GREY OWL
}

\author{
by ALEX ZELLERMEYER*
}

He was an Indian. He was a halfed. Or was he an Englishman? He an author, a naturalist, a lecturer. man presented to Prime Ministers Kings. He was a drunkard. haps a bigamist?

o most people of the past and, ununately, even the present, he was a stion mark. A man known more by hor than fact - judged more by sip than reality. Where does the th lie?

EARLY YEARS. The story of Grey began far from Prince Albert tional Park. It started in 1888 with birth of Archibald Stanfeld laney in the southern English istal town of Hastings.' Decades uld pass before Grey Owl would erge.

Archie's early childhood was typical most English school boys at the end the 19th century. His education was ked after by the two maiden aunts o had raised him from infancy. Are was particularly talented on the no. ${ }^{2}$

ike most schoolboys of his day, Are lived a constant daydream of exiencing the world of the North herican "Wild West". These dreams becoming an Indian pathfinder - a ter - were to follow him from ldhood through adolescence and, entually, to manhood.

By the age of 17, Archie was too tless to remain in Hastings with his aging aunts. The thought of set-

ince Albert National Park,

askesiu, Saskatchewan. tling into the local office clerk's position he seemed destined to occupy encouraged his growing wanderlust. In 1905, Archie Belaney booked passage on the S.S. Canada from Liverpool, arriving in Canada in April of that year."3

At the turn of the century, northern Canada was a country of wildlands, occasionally broken with mining towns, lumber camps and train stops on railroads to places of greater importance. Into this Ontario northland came Archie Belaney. At a small rail stop called Temiskaming, Archie made friends with the local Indians, trappers and guides. ${ }^{4}$ They were mostly of Ojibway origin, a people to whom Archie would alway credit his woodland talents. It was here that over the years that Archie Belaney learned the arts of trapping and wilderness life.

In 1910 Archie married his first wife, a young Ojibway girl named Angele. ${ }^{4}$ The marriage was to last for only a year. Archie's restlessness, which he felt whenever he became too "settled", was a personal uneasiness which would haunt him for his entire life. However, the Ojibway customs of marriage were simple. A couple remained together for as long as they desired or parted whenever they wished." Archie was taking on more of an Indian identity with each passing year.

Little is known of Archie's life from the period 1910 to 1915 . He spent one winter with his second wife, Marie Gerard. He worked with the Ontario Forestry Department near Biscotosing where he had the occasional run-in with the local constabulary." Archie was fond of "whooping-it-up" 


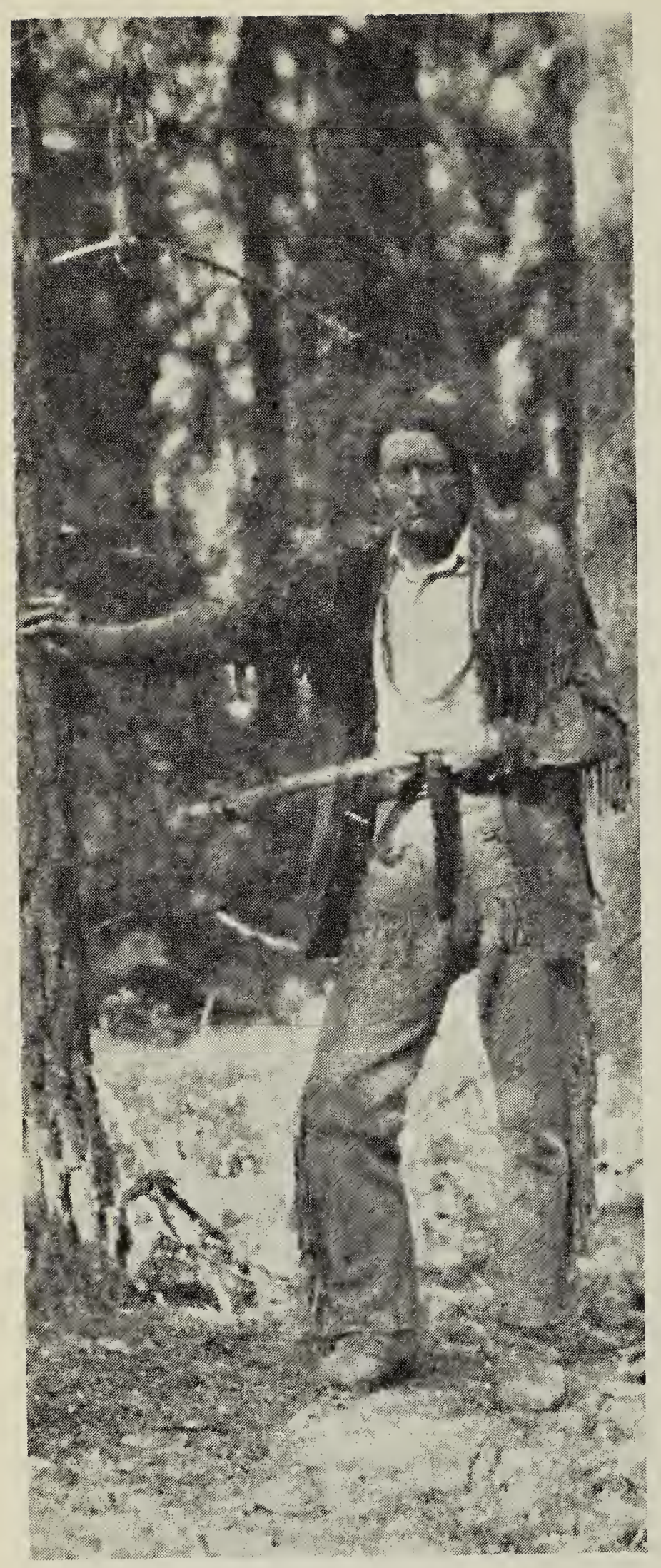

PRIVATE BELANEY. The onset of World War I saw the first Canadian contingent fighting under their own command and colours. Listed with this Canadian Expeditionary Force was Private A. Belaney. In France, Archie was wounded and subsequently sent to England for convalescence. ${ }^{\top}$ Back in his boyhood country, he spent over a year renewing old friendships and memories. One of these was his childhood sweetheart Ivy Holmes. In 1917 they were married.
It was here that Archie must hav finally decided that a well-ordere life, especially a rigid English one could never truly satisfy him. After months, the couple decided to dissolv the union." Archie Belaney wa Canada-bound for a second time When England saw him next it woul be as the triumphant Grey Owl.

GREY OWL. Back in the Ontario north woods near Biscotosing, Archie retur ned to the life of a trapper and guide It was in 1920 at an Ojibway gatherin that Archibald Belaney gave up hi Christian name. With his hair long an braided, clothed in buckskin, he chos the name Wa-sha-Quon-Asin, the Gre Owl." Not until his death would emerge that he had ever been know by another name.

Now, as Grey Owl, he continued hi trapping. It was circumstance tha returned him in 1920 to th Temiskaming area where he met Ger trude Bernard, a young girl o Iroquois descent. Grey Owl called he Anahareo - her ancestral name. Afte several months of correspondence the were married. ${ }^{x}$

PILGRIMS OF THE WILD. By the tim Grey Owl had met Anahareo he wa familiar with the value systems of th Ojibway, with their customs, and wit their language. He was, for all intent and purposes, an Indian in bot manner and appearance - especiall in appearance. Even his blue eyes an flawless English did not lessen the im pact of this tall, long-haired man $i$ moccasins. With a single eagle feather hanging from his braided hai and a determined scowl perpetually o his face, it appeared as though he ha stepped from the very pages of thos books he had read long ago i England.

These early years with Anahare changed Grey Owl from trapper $t$ conservationist. In the overhunte trapping regions of Ontario an Quebec, Grey Owl found it in 
easingly difficult to trap for a velihood. Since 1670, when the B.C. ship Nonsuch sailed from igland to the new-found fur lands of hat was to become Canada, the aver had started a slow but steady pulation decline. Two hundred and ty years later, in Grey Owl's time, it emed as though the last refuge for ir national animal was destined to be the Canadian nickel.

One spring, Anahareo found two orlaned beaver kittens. Their parents id been trapped, and it appeared that e fate of these kits was bleak. The pung couple adopted the orphans. ${ }^{11}$

Grey Owl was so moved by the inlligence and loyalty of these "beaver cople", as the Indians called them, at he became more concerned with nding measures to protect them, ther than better methods to trap em.

It was then that Grey Owl's fortunes iproved. A nature article he had subitted to an English journal, Country ffe, gained immediate recognition. "1) he publishers were only too eager to learn more about this eloquent halfbreed from Canada's backwoods who went by the name of Grey Owl. They asked for more.

At the same time, Grey Owl agreed to lecture to an audience at Metis Beach. " By the end of the summer of 1927, the attention he had received convinced Grey Owl that conservation was to be his life's work.

\section{A NATURALIST IN THE NATIONAL}

PARKS. Success followed success. Grey Owl completed a series of articles for Forest and Outdoors while Country Life began negotiations for his first book. The men of the last frontier.

In 1931, Grey Owl accepted a position with the National Parks Service as a naturalist. His project - to re-establish beaver colonies in areas of the National Parks from which they had been long exterminated.

Thus, in April of 1931, Grey Owl arrived at Riding Mountain National Park in Manitoba." Unfortunately, the local conditions for establishing a beaver colony didn't meet Grey Owl's

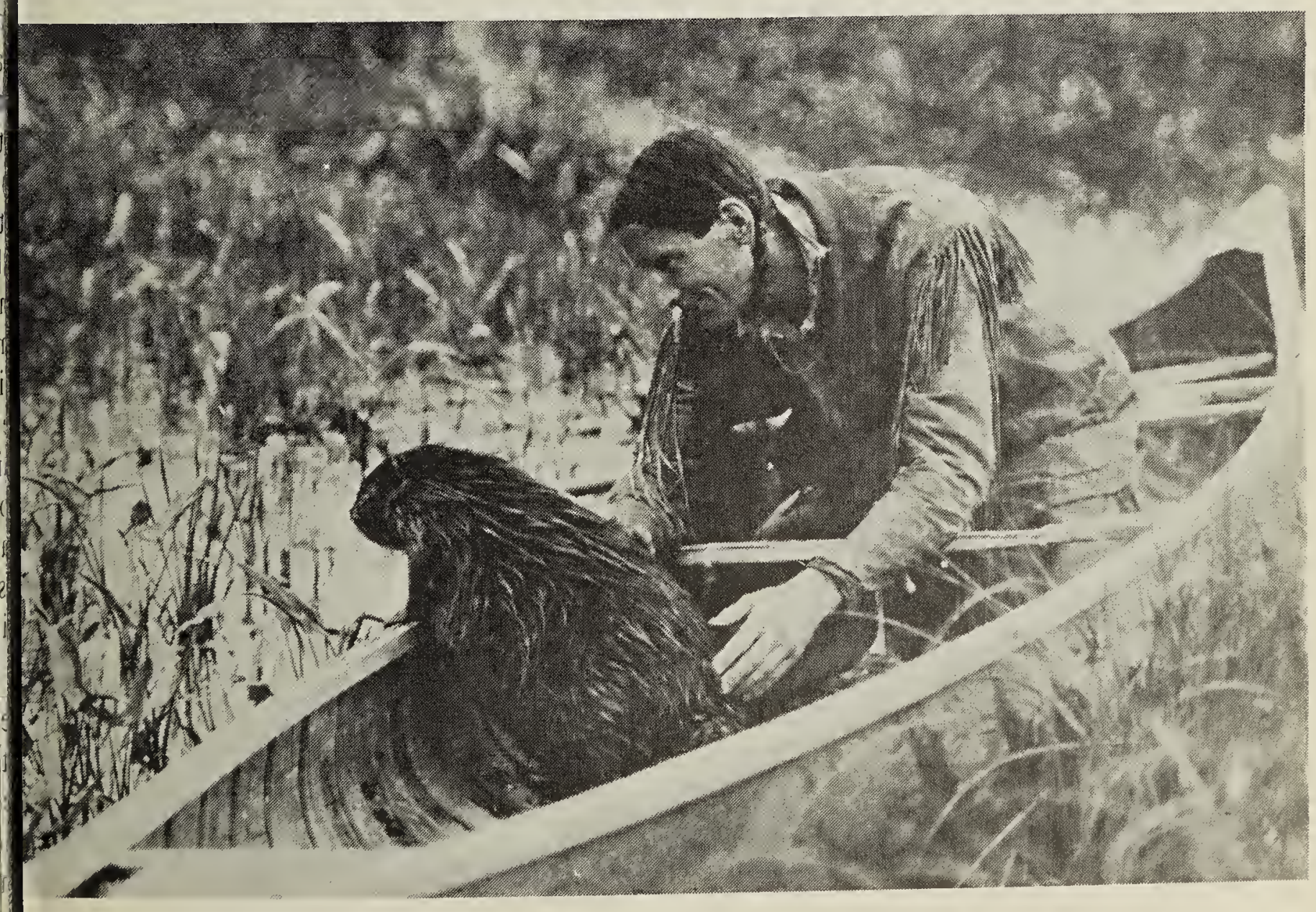


requirements and a transfer was requested." It was because of this that on October 27, 1931, Grey Owl, with Anahareo and the two beavers, Rawhide and Jellyrole, arrived in Prince Albert National Park." Here, on the seldom visited shoreline of a small lake called Ajawaan, a cabin was built. Grey Owl called it "Beaver Lodge". The name was more than appropriate. Rawhide and Jellyroll had built their mud lodge against it, and after a hole had been cut for them through the lakeside wall, they completed the other half of the lodge inside the cabin itself.

It was at Ajawaan that Grey Owl emerged from relative obscurity to become the celebrated Indian author and conservationist. He wrote articles and answered requests which never seemed to end. Streams of letters from the corners of the world flowed to Ajawaan.

During this period, 1932 to 1934, Grey Owl completed his best known work, Pilgrims of the wild. ${ }^{12}$ It was in this book that he told the story of Anahareo and the two orphaned beaver kits. It was also here that Grey Owl attempted to express his source of inspiration - the Canadian wilderness. Pilgrims of the wild was translated into eight languages so that there were few people in the western world who had not heard of the "Beaver Lodge" of this Canadian backwoodsman. ${ }^{1: 3}$

In 1935 Grey Owl agreed to his publisher's suggestion that he go on a lecture tour - destination: England. ${ }^{1: 3}$ Thus he returned to the country of his birth in beaded buckskin. Tall and stern-faced, he stood in front of more than a quarter of a million people on that tour alone. ${ }^{12}$ He filled and refilled theatres and still people were turined away for lack of space.

The tour was so successful that more were planned. On a subsequent lecture series in England, Grey Owl made a command appearance before $\mathrm{K}$ in George VI and the Royal family. ${ }^{14}$ Af terwards, having been asked for te with the sovereign, Grey Owl bade th king goodbye with a "Farewel brother" and a hearty slap on the bacl For the former Hastings resident thi must have been more than memorable occasion.

It is difficult to tell if Grey Owl him self realized the following he hac created. His work on beaver conser vation was continued throughou Canada, and because of the attention he focussed on preservation, a countr. whose existence was founded on resource extraction was quickly war ned that if her successes were to con tinue, she would have to adopt a mor moderate attitude to the land. As hi put it...

"I think the Canadians take thei priceless heritage of the Nort rather complacently for granted Well, they want to watch it, or the soon won't have it. The policy the are pursuing in regard to its ex ploitation and to a very much lesse degree, its preservation, is lamen tably short-sighted. ${ }^{1.5}$

THE PRICE OF FAME. The lengthy lec ture tours, writing schedules an world publicity also took their toll. I 1936 Grey Owl and Anahareo agreed to part. Later that year he married hi fifth wife, Yvonne Perrier, and com pleted his last book, Tales of an empt. cabin. 16:

In the autumn of 1937 Grey Owl un dertook another European lectur tour. Returning to North America, h immediately started yet another lec ture series in eastern Canada and th United States. ${ }^{\text {The }}$ pressures of hi travels, writing deadlines, and his lif style wore away Grey Owl's health. A he told one reporter in Ontario, on more month of this "will kill me". "I I did. A month later, April 3, 1938 Grey Owl passed away in a Princ 
pert hospital after being found unascious on the floor of "Beaver dge". He had pneumonia.

EY OWL EXPOSED. The day after his th Grey Owl was exposed as an iposter". "It had been only a matter ime before someone connected him Archibald Belaney, and when it hpened, no holds were barred. He came publicly associated with ud and scandal. People were more erested in his masquerade than his tings. The number of his wives was re important than his effort to fur- $r$ Canadian conservation. The pride encouragement he gave to native oples and their traditions was set de for the sensationalism of his love "whooping-it-up". And when the blic was tired of the expose and fir own moralizations, he became as forgotten as yesterday's newspapers

Yet, it is time which becomes the final judge of a person's accomplishments, and it is time that the words and thoughts of Grey Owl have survived. His books are regaining popularity and he may yet become recognized as one of Canada's greatest northern writers, as he was called before his death. One saner journalist wrote after Grey Owl's death, "He was not, they say, a real Red Indian. So what?"1s

Regardless of what Grey Owl was not, today we may be certain of what he was. He was an exceptional author and naturalist. He was a perceptive man whose life style demanded that he cast his fortune to the wind - no matter what. He was a great Canadian. The sadness is that it has taken us so long to realize it.

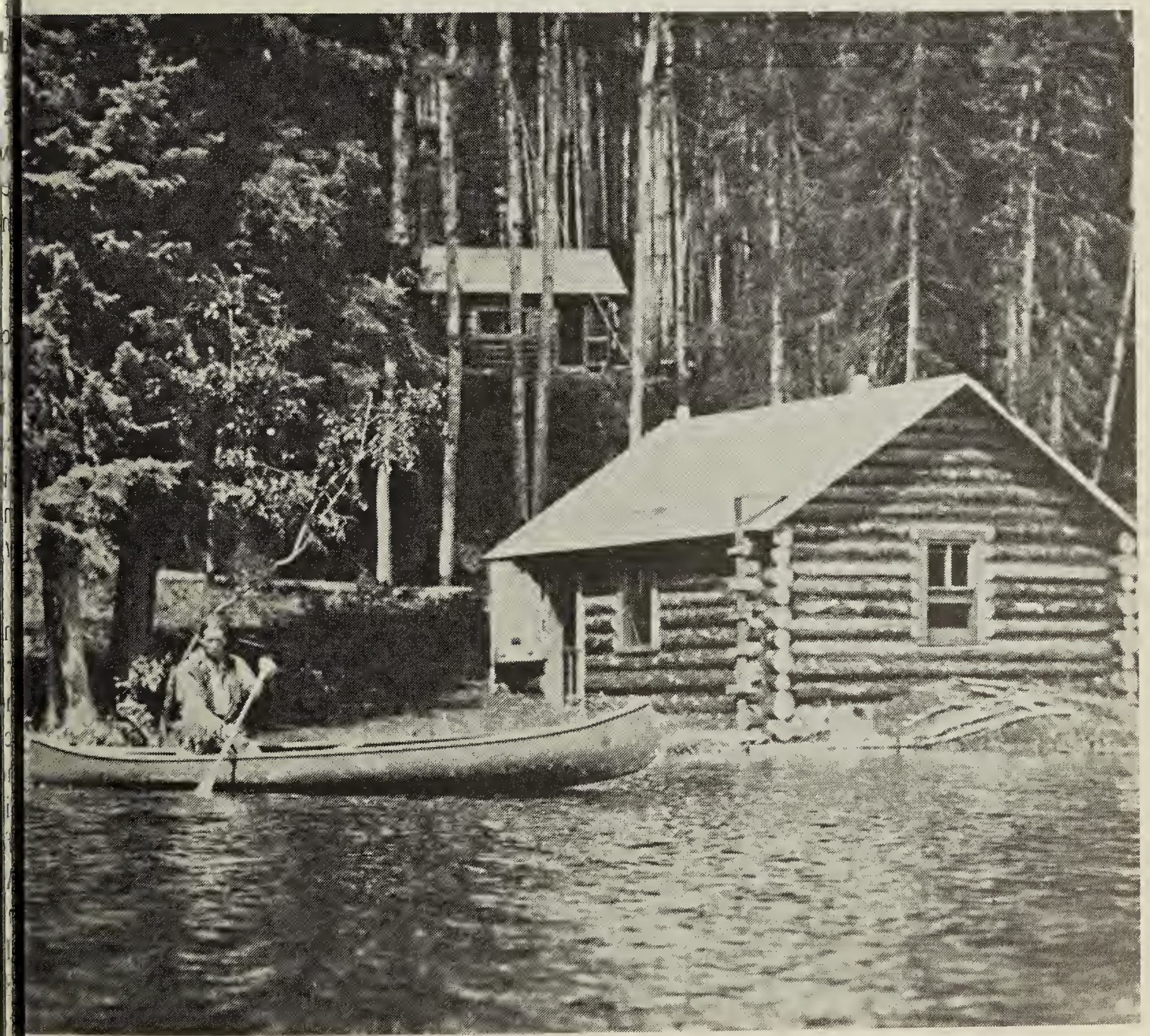




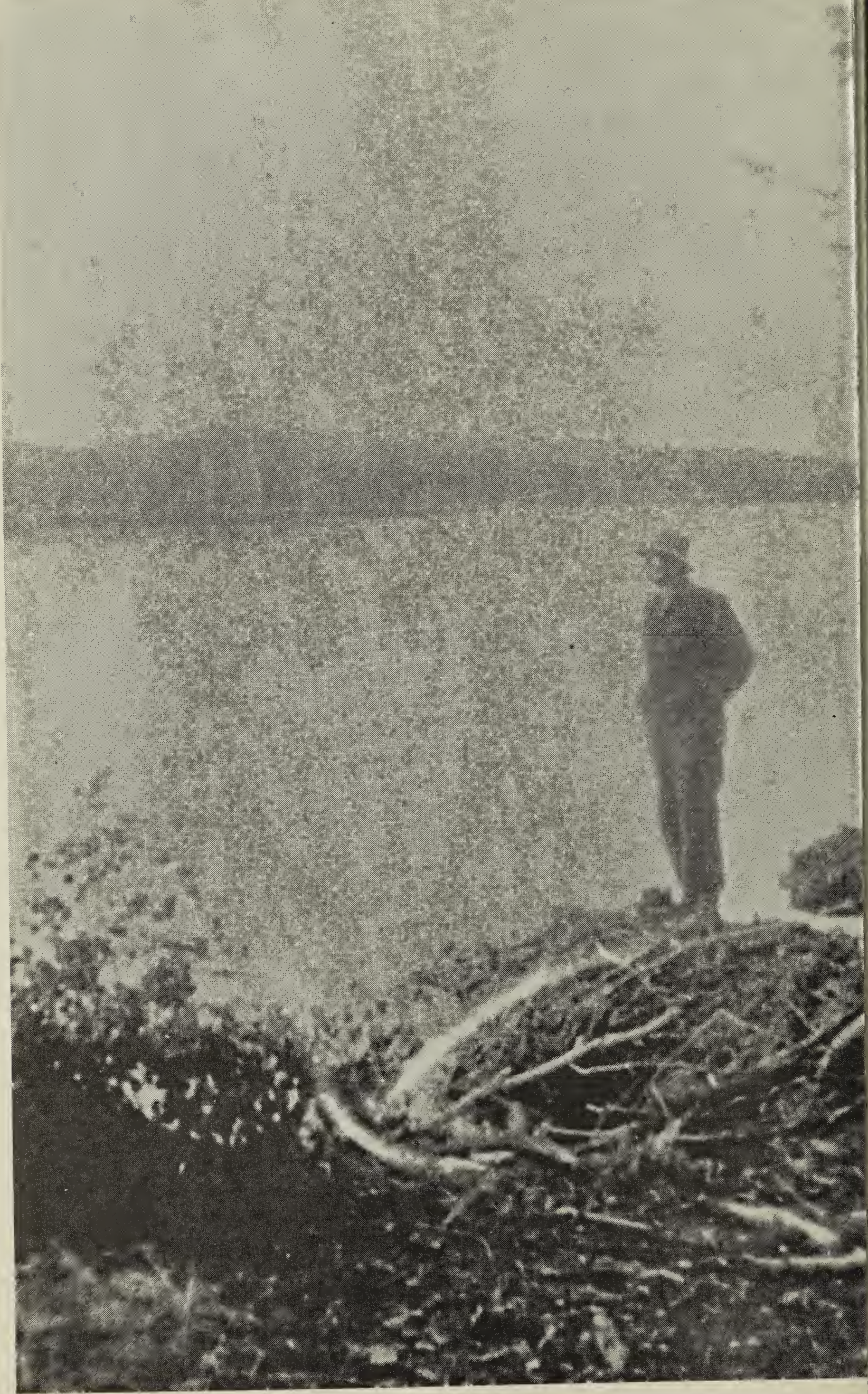

Blue J 
SHORT, G. C., 1971. The Grey Ow/ Project, p. 18. Univ. Saskatchewan.

SMITH, D., 1971. Grey Owl, p. 3, Univ. Toronto. sMITH, p. 25, No. 12. (Also some discrepancy in SHORT report p. 18).

SHORT, p. 19.

SMITH, p. 8.

SHORT, p.20 and SMITH, p. 7-8.

SHORT, p. 20.

SHORT, p. 21.

SMITH, p. 12.

SHORT, p. 22.

SHORT, p. 23.

SHORT, p. 25.

SHORT, p. 28.

SHORT, p. 27.

DICKSON, L., 1938, The Green Leaf, L. Dickson Pub., London, p. 61.

SHORT, p. 26-27.

SMITH, p. 27.

DICKSON, p. 48.
Books by Grey Ow!

The men of the Last Frontier. 1931, Country Life Ltd., London, 253 pp.

Pilgrims of the Wild. 1935, MacMillan Company of Canada, Toronto, $282 \mathrm{pp}$.

Sajo and Her Beaver People. 1935. Peter Davies Ltd., London, 208 pp.

Tales of an Empty Cabin. 1936, Peter Davies Ltd., London.

The Tree (from Tales of an Empty Cahin). 1937, Lovat Dickson Ltd., London, 62 pp.

\section{Books about Grey Owl}

A book of Grey Owl, Reynolds, E. E.

Half Breed, Dickson, L.

Wilderness Man, Dickson, L., 1973, MacMillan Co. of Canada, 283 pp.

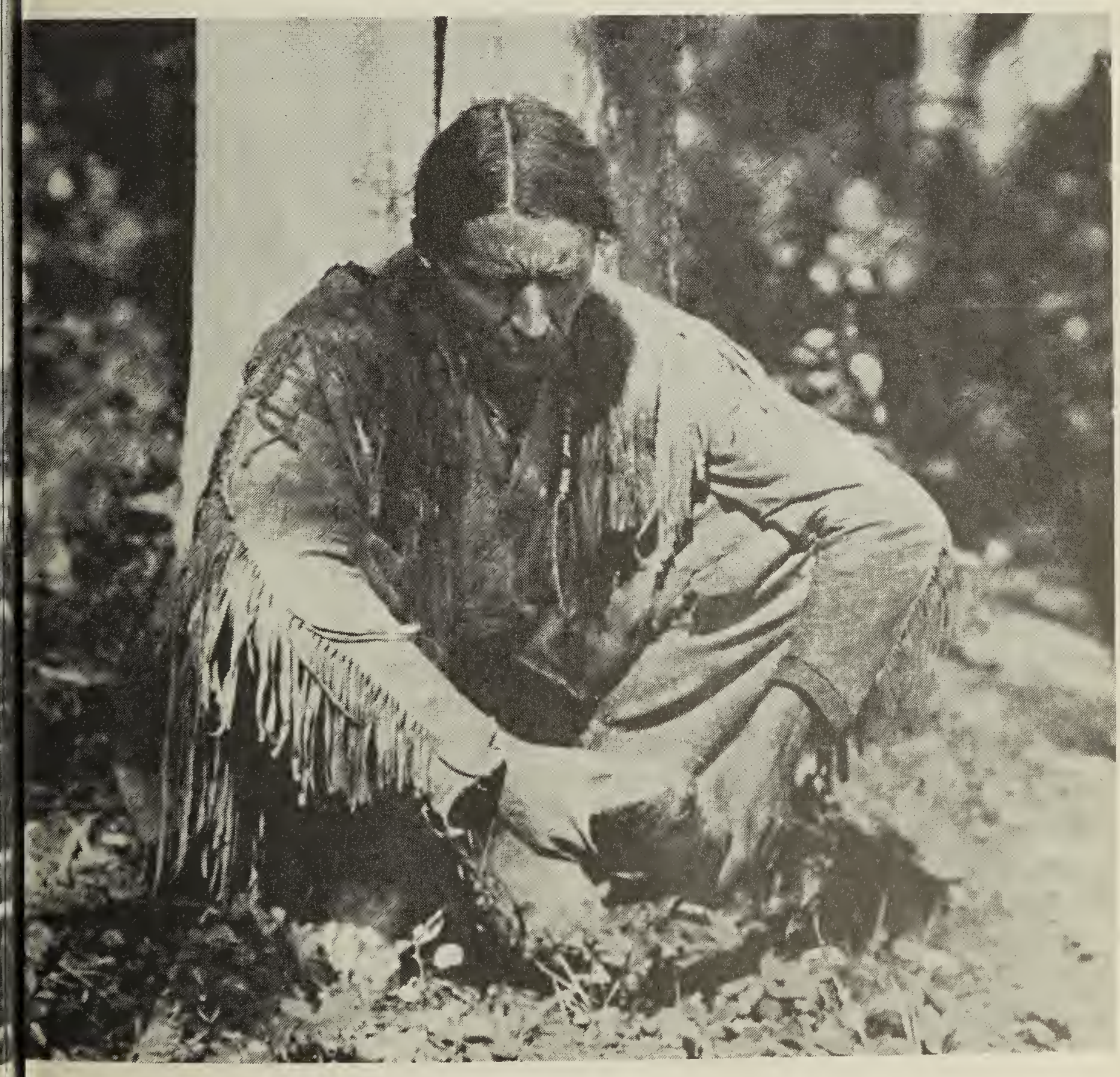

